\title{
Macroeconomic and financial determinants of non-performing loans: Evidence from PIIGS
}

\author{
Panagiotis Magdalinos ${ }^{1}$ and Ioannis Tsakalos ${ }^{2}$
}

\begin{abstract}
The Eurozone Debt Crisis led to the outbreak of non-performing loans (NPLs). The purpose of this paper is to identify the macroeconomic and financial factors that enhanced the non-performing loans. We compare the impact of financial crisis to the following countries: Italy, Greece, Spain, Portugal, Ireland (PIIGS) and focus on specific parameters which affect the banking sector. We apply panel data analysis to highlight the relation among NPLs and specific parameters: Gross Domestic Product (GDP), unemployment rate, bank liquidity, and the real estate market. Findings confirm the negative correlation between NPLs and the GDP and the housing prices, as well as the positive one with the unemployment rate and the liquidity ratio (LDR).
\end{abstract}

JEL classification numbers: G01, G20, G21

Keywords: Non-performing loans, panel data, macroeconomic factors, financial ratios

\section{Introduction}

The recent economic crisis had a devastating effect on the global economy. The rise of NPLs created huge problems on real economy worldwide. European countries could not be an exception. Both strong European economies (Germany, France) and weaker ones (Greece, Italy, Spain) suffered a lot by wealth losses and credit disturbances during the crisis. The economic slowdown and the decrease on the profitability and financial soundness of the banking sector led to tightening lending rules, market stagnation and rise of non- performing loans. Banks were more reluctant to lend money and tried to minimize their exposure to high-risk portfolios in accordance with the guidelines of the European Central Bank (ECB, 2020). Consequently, there was a significant liquidity problem which led firms with credit exposure or companies with debt facing huge economic difficulties. As a result, consumption and investment decline and the recession becomes deeper and the NPLs rise.

This study tries to identify the main factors that affect the NPLs, focusing on the countries that were mostly affected by the crisis (Portugal, Italy, Greece, Spain, and Ireland).

The purpose of this research is to determine the factors that explain the NPLs evolution. It is highly important for the financial system to identify the factors that affect the NPLs in order to monitor the warning indicators as early as possible and react effectively. So, the findings of the research can be useful for banking and market supervision.

\footnotetext{
${ }^{1}$ National and Kapodistrian University of Athens MBA, Greece

${ }^{2}$ Department of Accounting \& Finance, University of Thessaly and National and Kapodistrian University of Athens MBA, Greece
} 
Our study adds to existing literature on the determinants of NPLs by employing both macroeconomic variables as well as the real estate index. Macroeconomic indicators such as GDP and unemployment are very sensitive to economic cycles and difficult to predict or affect them. Although, banks can use them as signs and adapt relevant financial policies. Results also confirm that real estate prices and the bank liquidity are decisive for the design of the NPL management.

This study contributes to the NPLs literature by examining the sensitivity of NPLs to the economic depression. Among the vast literature we focus on countries with significant economic problems (PIIGS) and we attempt to quantify the effect of macroeconomic factors on banks portfolios using aggregated data of these countries during the financial crisis period (2008-2017) and employing the panel data model using Estimated Generalized Least Squares Model (EGLS) with random effects in order to estimate the correlation of these factors with the NPLs. Systemic risk increased dramatically, and banks credit exposure was underestimated. Despite the efforts of credit and governmental institutions in these countries, NPLs remain high even in the post crisis period. Study also suggests the housing prices and banks' liquidity are important factors in the evolution of NPLs.

The rest of the paper is organized as follows: Section 2 highlights the literature review regarding the NPLs and section 3 conveys the data used and the methodology employed. Section 4 contains the empirical results, and our study's conclusion is stated in the final section.

\section{Literature review}

There is a bunch of research studies which focus on banks' NPLs. The main factor categories are the macroeconomic factors, such as GDP, unemployment, inflation and interest rates, and the bank-specific ones, namely liquidity, profitability and capital adequacy.

The surveys conducted, concerned either individual countries (Louzis et al (2010); Salas and Saurina (2002); Quagliarello (2007); Arpa et al (2001); Skarica (2013))) or a group of countries (Glen and Mondragon Velez (2011); Makri et al (2014); Berge and Boye (2007); Nkusu (2011)).

Berger and DeYoung (1997) studied the relationship between loan quality and management decisions, using a data set from US commercial banks from 1985 to 1994. They concluded that bad management practices are related to credit risk. Subsequent surveys examining this relationship between bank management and loan quality [Salas and Saurina (2002); Podpiera and Weill (2008); Louzis et al (2010)] also show a negative relationship and a high number of NPLs.

Godlewski (2004), using a sample of banks from 30 developing economies in the period 1996-2001 and Podpiera and Weil (2008), focusing on Czech banking sector during the period 1994-2005, analyzed their main financial ratios - such as Return on Assets (ROA) and cost efficiency - to explain the increased risk. According to their studies, there is a negative correlation between the ROA with NPLs, while less aggressive banks were safer.

Glen and Mondragon-Velez (2011) used a sample of 22 developed countries to investigate banks capital adequacy and NPL-related losses during the 1996-2008 period. Authors concluded that banks with low capital adequacy tend to adopt higher credit risk.

Garciya and Robles (2008) showed a positive relationship between the future risk of non-performing loans and the Return on Equity ratio (ROE) in their survey on the Spanish banking industry (panel data of 129 banks) from 1993-2000. Banks, in their quest to achieve higher profits and attract more investors, provided high-risk loans which - in the short term - increased their profitability and received better ROE ratio. However, in the long run, the increased credit risk and the number of NPLs increased too.

Louzis et al (2010) employed the Generalized Method of Moments (GMM) to study the Greek banking sector from 2003 to 2009. Authors showed the relation among NPLs and different factors, such as GDP 
rate, unemployment rate, interest rate, public debt and poor management. Similar were the results of Salas and Saurina (2002) and Abid et al (2013).

Anastasiou et al (2017) examined the Eurozone NPLs, for both strong economies (Austria, Belgium, France, Germany, Finland, Lithuania, Luxembourg, the Netherlands and Slovakia) and PIIGS. They employed Fully Modified OLS and Panel Cointegrated VAR methods to analyze data for a 10 years period (2003-2013). Their findings support the importance of GDP for the strong economies, while PIIGS were positively affected from liquidity, interest rates and bad management, while banks' size is negatively correlated.

Skarica (2013), employed panel data analysis to study the main NPLs contributors in the following countries: Croatia, Bulgaria, Czech Republic, Latvia, Slovakia, Hungary and Romania. Researcher concluded the negative impact of GDP, while inflation and unemployment had a significant positive effect. Makri et al (2014) showed that NPLs are positively related with the unemployment rate and public debt, but negatively with the GDP. Authors also highlighted the importance of banks' liquidity which declines when NPLs rise.

Berge and Boye (2007) highlighted the importance of unemployment rate and real interest rate, while Espinoza and Prasad (2010) employed dynamic panel data (panel VAR) to identify the main NPL determinants for 80 banking institutions of the Gulf Cooperation Council (GCC) for the period 19952008. According to their research, there is a negative correlation between NPLs and GDP and a positive correlation with interest rates which is also confirmed by Fiqiri et al (2015).

Arpa et al (2001) and Rinaldi and Sanchis-Arellano (2006) confirmed the real estate prices as a significant parameter for NPLs, beyond GDP, unemployment, inflation and real interest rates. Monokroussos et al (2016) also dealt with the so-called home equity hypothesis. In their research on Greek NPLs, they highlighted the significant role of mortgage/residential loan terms in the rise of NPLs in Greece. Before crisis, many borrowers used funds for housing purposes, such as home improvements, but also for consumer purposes. Their research showed that rising real estate prices affect consumer loans more than business loans or mortgages. In any case, the rise in NPLs was mainly due to the shrinking GDP and the rising unemployment.

Messai and Juini (2013) used macroeconomic indicators (GDP, unemployment and interest rates) and financial ratios [ROA and loan loss ratio (LLR/TL)] in a panel data analysis for 85 banks in Greece, Italy and Spain. Their findings support that NPLs are negatively correlated with GDP and ROA and positively with unemployment, interest rates and LLR / TL. Quagliarello (2007) concluded that macroeconomic environment affects banks' credit risk and profitability during the recession period.

Bonfondi and Ropele (2011) argue that an increase in Italian NPLs was inevitable given the conditions of the Italian economy. The heavy reliance on the construction industry and the high leverage of the private sector were among the main factors that exposed the Italian economy to NPL, when the crisis broke out. Nkusu (2011) also dealt with the sensitivity of loan quality when the macroeconomic environment changes. Nkusu used panel data for 26 developed countries for the period 1998-2009 and concluded that banks' performance is affected by unemployment rate, GDP, stock market and housing prices. Furthermore, Beck et al (2013) added to the literature the exchange rates and share prices in addition to the GDP and interest rate.

Ari et al (2019) dealt with the dynamic NPL relationships during 88 banking crises since 1990 in 78 countries. Their research revealed a strong link between NPLs and the intensity of the post-crisis recession. NPLs are affected by changes in business cycles, but mishandling them, slows down the recession. The results are very important for the prevention and management of NPLs in times of recession. Government debt, exchange rate, business debt and credit size are the factors that governments and banks need to pay attention to. Finally, they suggest that it is crucial to create an appropriate legal environment to facilitate the service of NPLs and control the banks and the borrowers. 
During recession periods, financial ratios, share prices and real estate prices decline, while unemployment rate and NPLs rise. This study attempts to examine the main factors for period 2009-2019 by employing panel data analysis.

\section{Data and Methodology}

Figure 1 presents the evolution of private credit during the pre-crisis period (2001-2009). Given the credit exposure, both creditors and borrowers were vulnerable to changes. When market collapsed, borrowers had limited funds to pay back their obligations and continuous bankruptcies created additional problems to lenders.

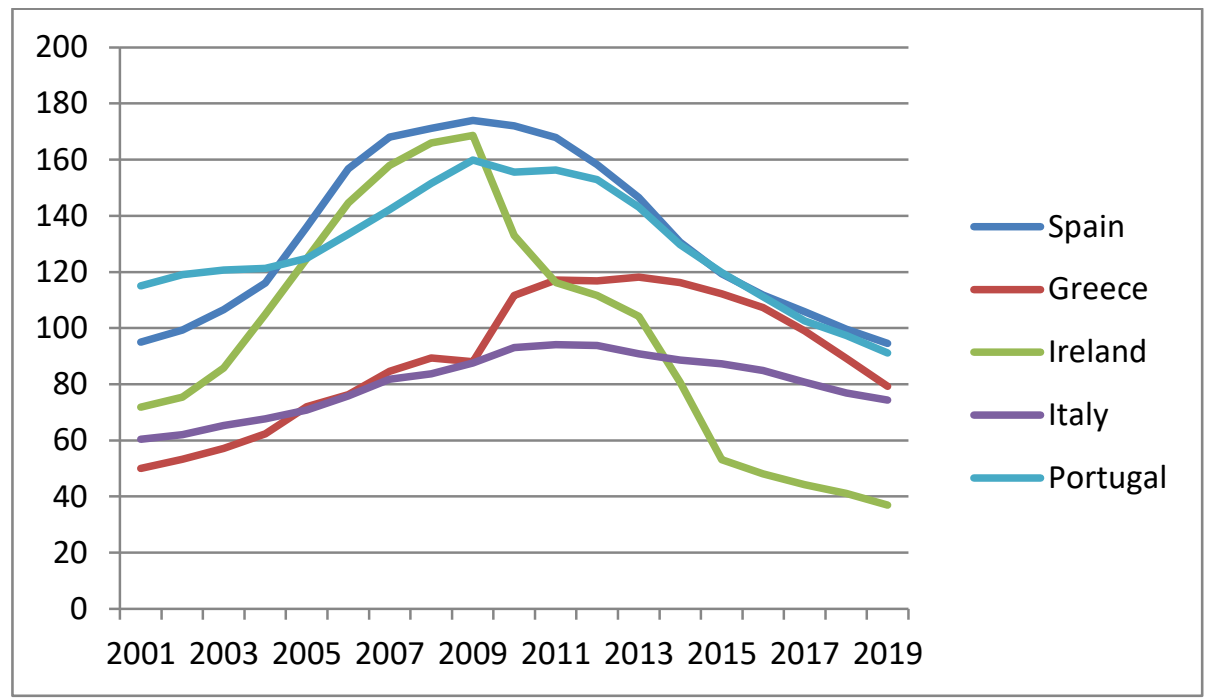

Figure 1: Domestic credit to private sector $(\% \mathrm{GDP})^{3}$

In order to quantify the NPLs' effect on banks performance, we used a variety of parameters namely GDP, unemployment rate, Total Loans / Total Deposits (TLTD) and Housing Price Index.

GDP and unemployment rate have been commonplace in literature. We expect a negative relationship with GDP and a positive one with unemployment rate [Louzis et al (2010); Messai and Juini (2013); Makri et al (2014); Skarica (2013)]. Regarding the TLTD index, we are hesitant about the sign. In case the numerator increases, we expect a positive relationship with the NPLs, but in case the denominator changes concurrently, the pace and direction of the change is important. This ratio is related to the liquidity of banks (Makri et al). Regarding housing prices (Arpa et al (2001); Rinaldi and SanchisArellano (2006)), we expect a negative relationship, as the price of real estate is related to the borrower's property and therefore to the possibility of repaying the loan. Those variables' fluctuation is presented in the following figures.

\footnotetext{
${ }^{3}$ World Bank (2019). Domestic credit to private sector (\% of GDP) Available at: https://data.worldbank.org/indicator/FS.AST.PRVT.GD.ZS?locations=IT-GR-PT-IE-ES\&name desc=false
} 


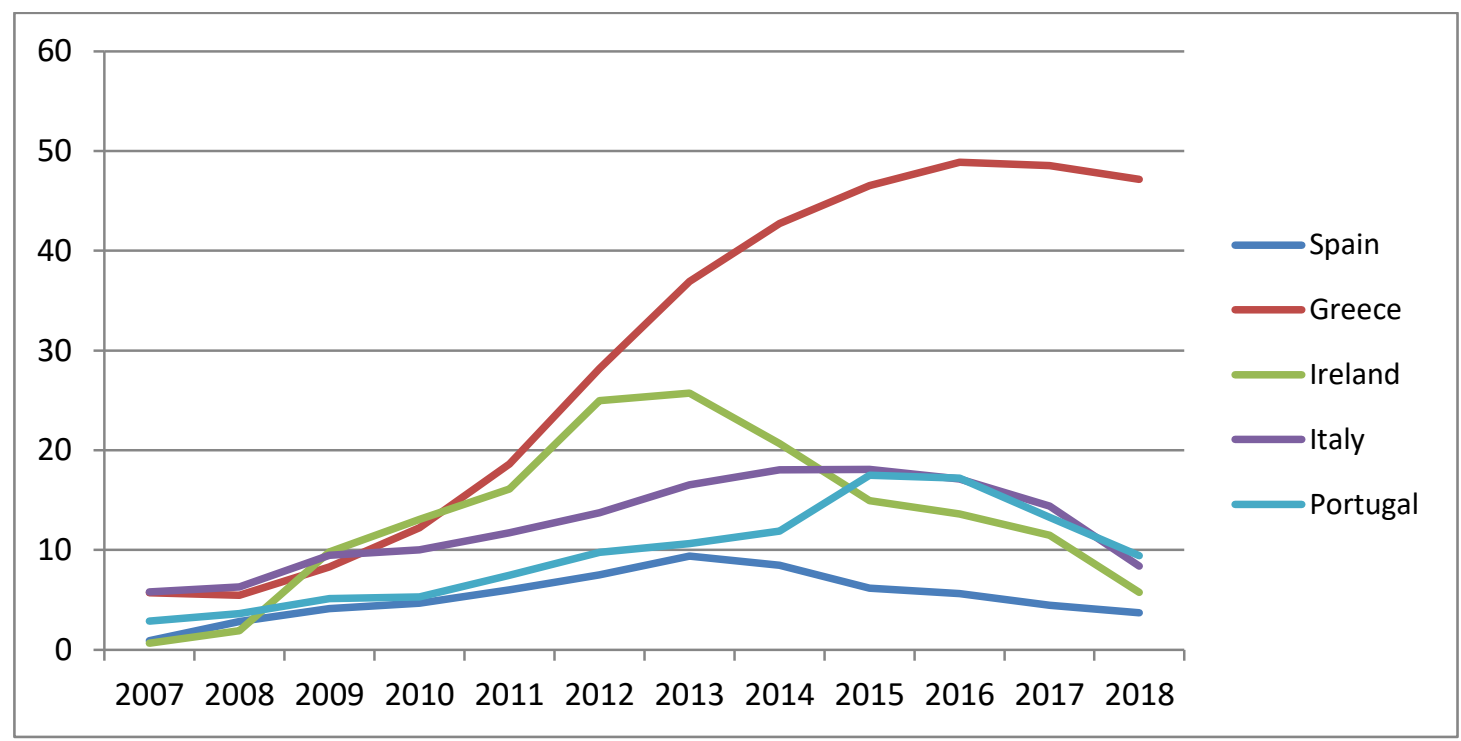

Figure 2: NPL ${ }^{4}$

Figure 2 presents the NPLs rise during the years 2007-2018 for PIIGS. Non-performing loans are expressed as a percentage of the total loans held by a bank. Figure 2 presents the value of NPLs in relation to the total loans that banks retain in their portfolio. The second half of 2008 is a benchmark for these countries, as it is the trigger point of the NPL's rise for all these economies. Unemployment rate is presented in Figure 3 where we observe a significant increase during the first years of the economic crisis (2008-2013) for all economies concurrently with the NPLs' rise.

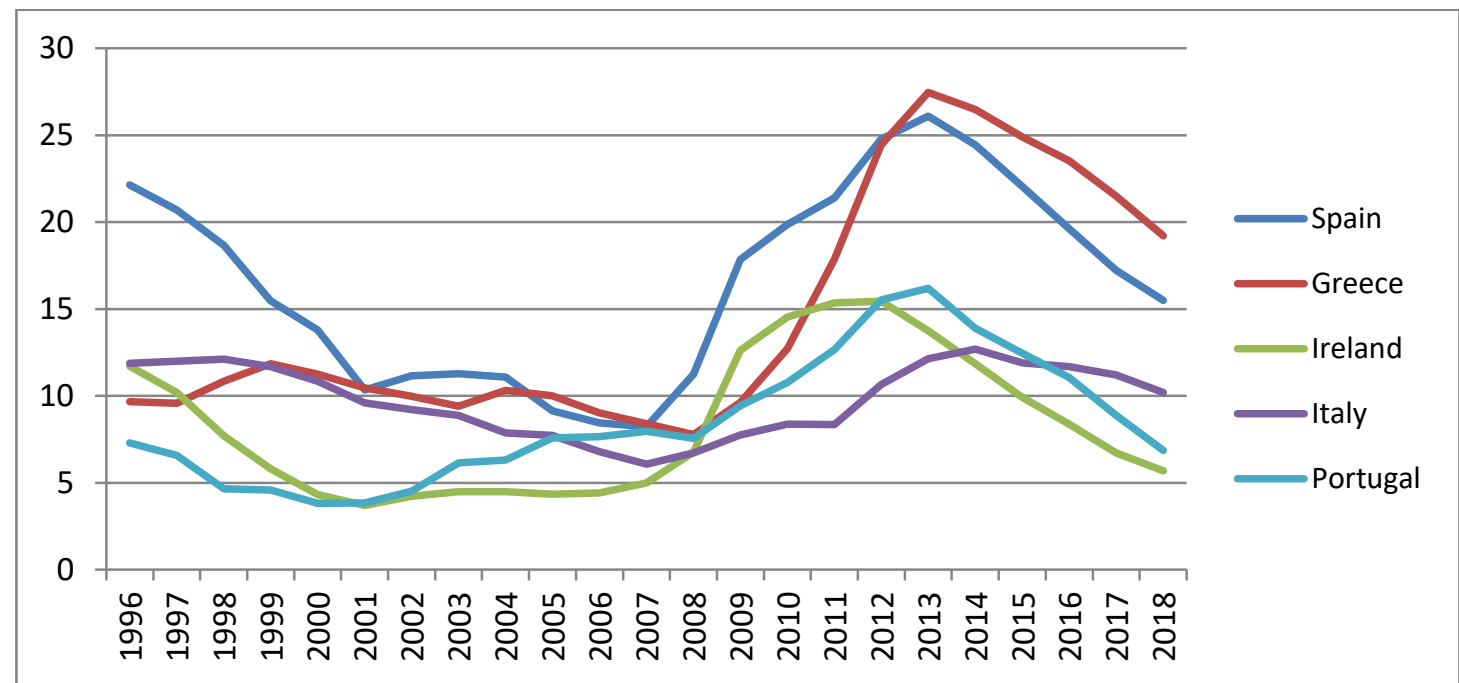

Figure 3: Unemployment Rate ${ }^{5}$

\footnotetext{
${ }^{4}$ World Bank (2019). NPL. Available at: https://data.worldbank.org/indicator/FB.AST.NPER.ZS

${ }^{5}$ World Bank (2019). Unemployment. Available at: https://data.worldbank.org/indicator/SL.UEM.TOTL.NE.ZS
} 
Obviously, when unemployment rises, the consequences are pictured also to the GDP level. Figure 4 shows the annual percentage growth of GDP at market prices based on constant local currency. Results confirm the literature since we observe a sharp decline the period 2008-2012 for the majority of the economies examined. Albeit there was a rebound on previous years levels, market dynamics didn't allow its growth further.

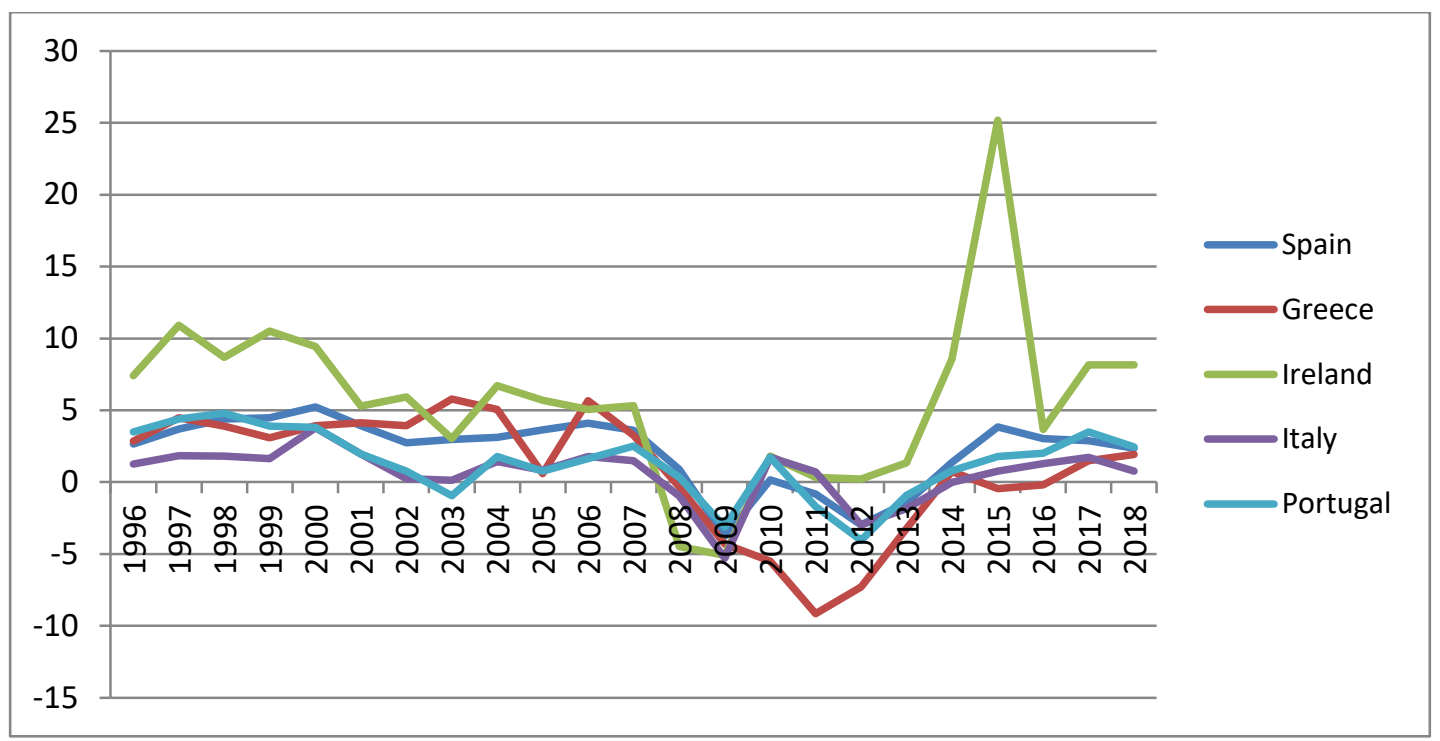

Figure 4: GDP ${ }^{6}$

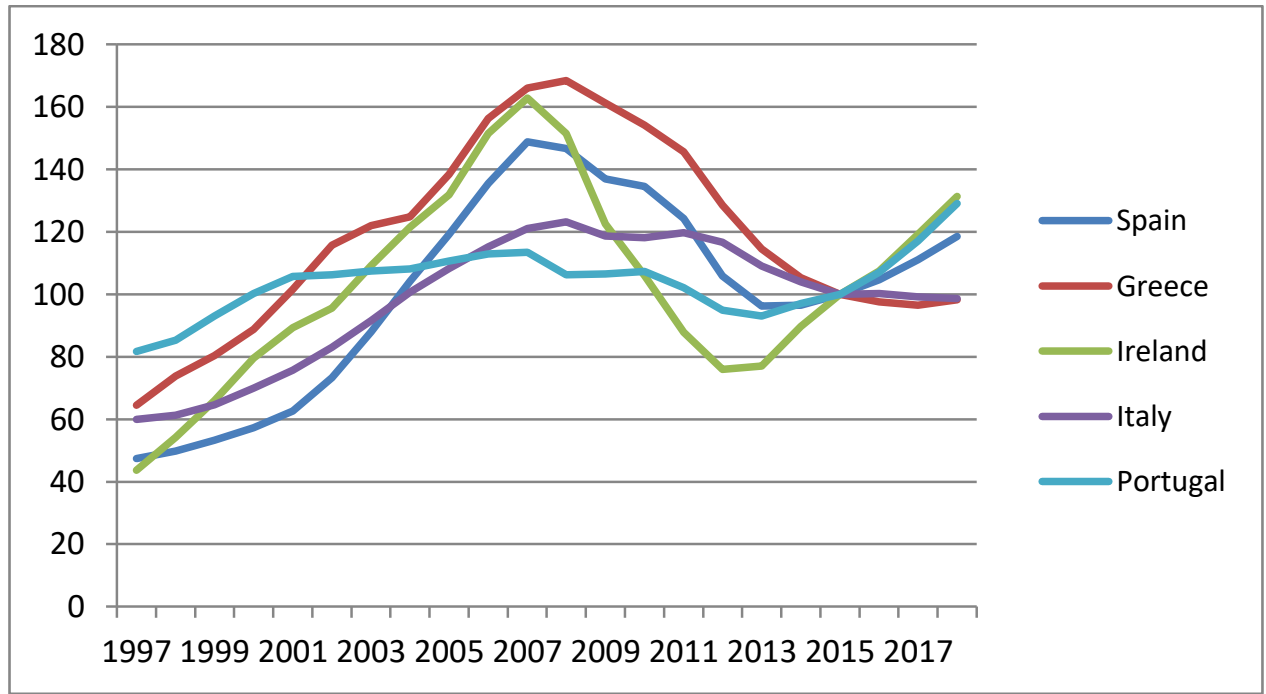

Figure 5: Real Estate Price Index ${ }^{7}$

\footnotetext{
${ }^{6}$ World Bank (2019). GDP annual growh (2019). Available at: https://data.worldbank.org/indicator/NY.GDP.MKTP.KD.ZG World Bank (2019). GDP per capita annual growth. Available at: https://data.worldbank.org/indicator/NY.GDP.PCAP.KD.ZG ${ }^{7}$ OECD (2019). Housing Prices. Available at: https://data.oecd.org/price/housing-prices.htm OECD (2019). Value Added by Activity (Construction). Available at: https://data.oecd.org/natincome/value-added-by-activity.htm
} 
Housing prices include housing rent prices indices, real and nominal house prices indices, and ratios of price to rent and price to income. The price to income and price to rent ratios are indices with base year 2015. According to Figure 5, real estate prices dropped gradually since the outbreak of the financial crisis.

In regard to the ratio Total Loans/Total Deposits (LDR), which is used as a liquidity ratio, we used quarterly data obtained from the European Central Bank (ECB). Quarterly data were converted to annual data using the weighted average. The weighted average for each year was as follows:

$$
L D R_{x}=\frac{\mathrm{Q} 1_{\mathrm{x}}+\mathrm{Q} 2_{\mathrm{x}}+\mathrm{Q} 3_{\mathrm{x}}+\mathrm{x}}{4}
$$

$x=$ year, $2000,2001 \ldots 2019$.

Figure 6 presents the LDR index where we confirm the credit restrictions' results on loans levels as well as the ECB Emergency Liquidity Assistance (ELA). Liquidity injections improved LDR levels after 2012.

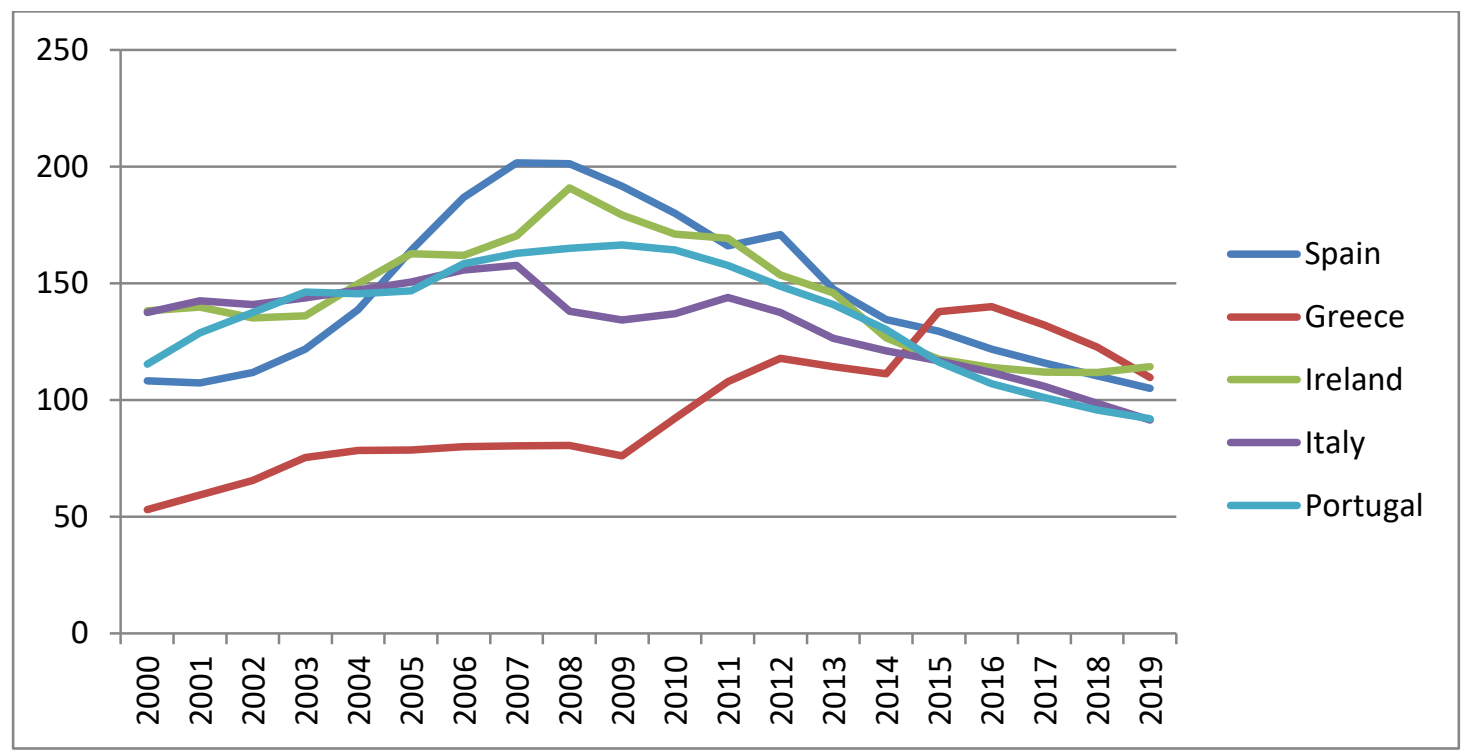

Figure 6: $\mathrm{LDR}^{8}$

In Table 1, we present the source of data set. We use annual data (period 2007-2018) expressed in time series with 55 observations for each variable. Macroeconomic indicators, as well as NPLs data were obtained from World Bank Group. The annual data for the TLTD index (period 2006-2018) were obtained from the European Central Bank. The data used for the regression were the first differences of each index since these countries have large differences in GDP and population. A regression model employed to find the causal relationship between the independent variables and the dependent one.

\footnotetext{
${ }^{8}$ LDR (2020). Available at: https://www.euro-area-statistics.org/banks-balance-sheetloans?cr=eur\&lg=en\&page $=2$ \&template $=1$
} 
Table 1: Presentation of variables

\begin{tabular}{|c|c|c|}
\hline Code & Variable & Source \\
\hline NPL & Non- Performing Loans/ Total Loans & $\begin{array}{c}\text { World Bank/Bank of } \\
\text { Greece }\end{array}$ \\
\hline $\begin{array}{c}\text { GDP per capita } \\
\text { (annual growth) }\end{array}$ & GDP per capita (annual growth) & World Bank \\
\hline UNEMPL & Unemployment Rate & World Bank \\
\hline TLTD & LDR & ECB \\
\hline HOUSECOST & Housing Prices & OECD \\
\hline
\end{tabular}

Due to limited data, we apply the panel data model. The main reason behind the restriction regarding time series was that banks started to monitor and record the NPLs during the financial crisis. Panel data model is appropriate for static and dynamic interdependencies and there is statistical induction even if time series are few (Wooldridge, 2009). Panel data enables us to control the bias generated by heterogeneity. We also used the first differences to avoid the problem of autocorrelation (Wooldridge, 2009).

The model is the following:

$$
\log (N P L)=\beta_{0}+\beta_{1} * \log (G D P)+\beta_{2} * \log (\text { UNEMP })+\beta_{3} * \log (\text { TLTD })+\beta_{4} * \log (\text { HOUSECOST })
$$

In order to choose between random effects and fixed effects we employed the Hausman test. The null hypothesis is that random effects are appropriate, while the alternative is that fixed effects are appropriate. The fixed effects assumption indicates that the individual effects are treated as correlated with the independent variables. The random effects assumption indicates that the individual-specific effects vary over time and variable. So, the individual effects are random and uncorrelated with the independent variables (Verbeek, 2012).

We then test our model for normality and residual cross-section dependence test. Normality test suggests that the residuals should follow the normal distribution. Residual cross-section dependence is tested by the Breusch-Pagan LM test. According to the Breusch-Pagan LM test (Table 5), the null hypothesis is that there is no autocorrelation in the panel residuals. Finally, there should be no correlation between the variables. The following section shows the empirical results of the research.

\section{Empirical Result}

According to the descriptive statistics of the first differences of the dependent and independent variables used in this empirical study GDP per capita ranges from -9 to 3.9 indicating, that some of the PIIGS showed negative annual growth for the period 2008-2018. Unemployment growth shows high disparity from 0 to 6.6 among the countries. The average and the median of the first differences of LDR are -4.25 and -5.47 , respectively. Thus, LDR variable grew negatively over the years. NPL variable shows high disparity from -6 to 9.6, while the real estate prices marked a negative average and median growth of -1.6 and -1.4 , respectively. 
Table 2: Descriptive statistics

\begin{tabular}{|l|c|c|c|c|c|c|}
\hline & GDP & HOUSECOST & NPL & NPL(1) & TLTD & UNEMP \\
\hline Mean & -0.321 & -1.594 & 1.064 & 1.086 & -4.243 & 0.396 \\
\hline Median & 0.220 & -1.428 & 1.289 & 1.301 & -5.468 & -0.004 \\
\hline Maximum & 3.916 & 16.542 & 9.564 & 9.564 & 26.572 & 6.603 \\
\hline Minimum & -8.998 & -19.153 & -5.997 & -5.997 & -23.333 & -2.422 \\
\hline Std. Dev. & 2.892 & 7.530 & 3.485 & 3.650 & 9.283 & 2.354 \\
\hline Sum & -17.697 & -87.685 & 58.518 & 54.303 & -233.365 & 21.803 \\
\hline Sum Sq.Dev. & 451.696 & 3061.882 & 655.784 & 652.873 & 4653.002 & 299.332 \\
\hline bservations & 55 & 55 & 55 & 50 & 55 & 55 \\
\hline
\end{tabular}

The results of the Hausman test are presented in Table 3 which suggests that the random effects model is the most suitable. The result according to Table 3 is $0.079>0.05$ so we cannot reject the null hypothesis. The model is acceptable according to the Breusch-Pagan LM test (Table 3), as the value 0.38 is greater than 0.05 and we accept the null hypothesis that there is no autocorrelation in the panel residuals. However, by checking the normal distribution of the residuals, we notice that the residuals are not distributed normally. According to Table 3 the null hypothesis is rejected $(0.00198<0.05)$, so we accept the alternative hypothesis, that the residuals are not distributed normally.

Table 3: Diagnostic Tests

\begin{tabular}{|c|c|c|c|c|}
\hline \multicolumn{5}{|c|}{ Correlated Random Effects - Hausman Test } \\
\hline \multicolumn{2}{|c|}{ Test Summary } & Chi-Sq. Statistic & Chi-Sq. d.f. & Prob. \\
\hline \multicolumn{2}{|l|}{ Cross-section random } & 8.368 & 4 & 0.0790 \\
\hline \multicolumn{5}{|c|}{ Residual Cross-Section Dependence Test } \\
\hline Test & Statistic & d.f. & Prob. & \\
\hline Breusch-Pagan LM & 10.755 & 10 & 0.3769 & \\
\hline \multicolumn{5}{|l|}{ Normality Test } \\
\hline Probability & 0.001984 & & & \\
\hline
\end{tabular}

To overcome this problem, we will set all the independent variables with a lag of one year. Alternatively, we set the dependent variable one year later $(t+1)$. The Hausman test (Table 4) indicates random effects again. The Normality test (Table 4) shows now that the residuals are distributed normally (p-value: 0.23> 0.05 ) and there is no autocorrelation according to the Breusch-Pagan LM test (Table 4). However, there is a multicollinearity problem (Table 4). GDP has a very strong correlation with unemployment but not with the house price index. The house price index has also a slightly negative correlation with unemployment rate which indicates that there is still multicollinearity. 
Table 4: Diagnostic Tests

\begin{tabular}{|c|c|c|c|c|}
\hline \multicolumn{5}{|c|}{ Correlated Random Effects - Hausman Test } \\
\hline \multicolumn{2}{|c|}{ Test Summary } & Chi-Sq. Statistic & Chi-Sq. d.f. & Prob. \\
\hline \multicolumn{2}{|c|}{ Cross-section random } & 2.865 & 4 & 0.5807 \\
\hline \multicolumn{5}{|c|}{ Residual Cross-Section Dependence Test } \\
\hline Test & Statistic & d.f. & Prob. & \\
\hline $\begin{array}{l}\text { Breusch-Pagan } \\
\text { LM }\end{array}$ & 11.530 & 10 & 0.3178 & \\
\hline \multicolumn{5}{|l|}{ Normality Test } \\
\hline Probability & 0.230818 & & & \\
\hline \multicolumn{5}{|l|}{ Multicolinearity } \\
\hline & GDP & UNEMP & TLTD & HOUSECOST \\
\hline GDP & 1 & -0.818 & -0.234 & 0.621 \\
\hline UNEMP & -0.818 & 1 & 0.209 & -0.680 \\
\hline TLTD & -0.234 & 0.209 & 1 & -0.159 \\
\hline HOUSECOST & 0.621 & -0.680 & -0.159 & 1 \\
\hline
\end{tabular}

Therefore, we have to exempt the GDP factor from the independent variables to avoid multicollinearity (Table 5). In addition, the residuals are distributed normally (Table 5), there is no autocorrelation (Table 5) and Hausman test indicates the random effects (Table 5). In Table 5, we present the regression results. $\mathrm{R}^{2}$ is $55.3 \%$, all variables are statistically significant at a $95 \%$ significance level and the form of our model is:

$$
\begin{gathered}
\log (N P L)= \\
0,95+0,41 * \log \left(\operatorname{UNEMP}_{(\text {lag-1) }}\right)+0,13 * \log \left(\text { TLTD }_{(\text {lag }-1)}\right)-0,18 * \log \left(\operatorname{HOUSECOST}_{(\text {lag }-1)}\right)
\end{gathered}
$$

The signs of the variables are compatible with economic intuition and the literature. All variables are statistically significant at a $95 \%$ significance level:

- Unemployment: $p$-value is $0,048<0,05$

- TLTD: $\mathrm{p}$ - value is $0,001<0,05$

- Real Estate Prices: p-value is $0,007<0,05$

Unemployment rate has a positive sign. It implies that a change of the rate at $1 \%$ influences positively $41 \%$ the NPL ratio. So, the rise of unemployment leads to the rise of NPLs and vice versa. The significance of unemployment rate is expected because unemployment leads to lower income and increased debts. Therefore, changes in the unemployment rate may lead to changes in the NPL ratio in the same direction. 
Table 5: Estimation Results

\begin{tabular}{|c|c|c|c|c|}
\hline \multicolumn{5}{|c|}{$\begin{array}{l}\text { Method: Panel EGLS (Cross-section random effects) } \\
\text { Dependent Variable: NPL(1) } \\
\text { Periods included: } 10 \\
\text { Cross-sections included: } 5 \\
\text { Total panel (balanced) observations: } 50 \\
\end{array}$} \\
\hline Variable & \multicolumn{3}{|c|}{ Coefficient } & Prob. \\
\hline $\mathrm{C}$ & \multicolumn{3}{|l|}{0.954598} & 0.0258 \\
\hline UNEMP & \multicolumn{3}{|l|}{0.414731} & 0.0480 \\
\hline TLTD & \multicolumn{3}{|l|}{0.132482} & 0.0011 \\
\hline HOUSECOST & \multicolumn{3}{|l|}{-0.18468} & 0.0068 \\
\hline \multicolumn{5}{|c|}{ Weighted Statistics } \\
\hline \multicolumn{2}{|l|}{ R-squared } & \multicolumn{2}{|l|}{0.553092} & \\
\hline \multicolumn{2}{|l|}{ Adjusted R-squared } & \multicolumn{2}{|l|}{0.523946} & \\
\hline \multicolumn{2}{|l|}{ S.E. of regression } & 2.519 & & \\
\hline \multicolumn{2}{|l|}{ F-statistic } & 18.977 & & \\
\hline \multicolumn{2}{|l|}{ Prob(F-statistic) } & \multicolumn{2}{|l|}{0.000000} & \\
\hline \multicolumn{5}{|c|}{ Diagnostics } \\
\hline \multicolumn{2}{|c|}{ Test Summary } & $\begin{array}{l}\text { st } \\
\text { Chi-Sq. } \\
\text { Statistic }\end{array}$ & Chi-Sq. d.f. & Prob. \\
\hline \multicolumn{2}{|l|}{ Cross-section random } & 3.476 & 3 & 0.3239 \\
\hline \multicolumn{5}{|c|}{ Residual Cross-Section Dependence Test } \\
\hline Test & \multicolumn{2}{|l|}{ Statistic } & \multicolumn{2}{|l|}{ Prob. } \\
\hline Breusch-Pagan LM & \multicolumn{2}{|l|}{11.982} & \multicolumn{2}{|l|}{0.2863} \\
\hline \multicolumn{5}{|l|}{ Normality Test } \\
\hline \multicolumn{5}{|l|}{ Multicolinearity } \\
\hline & UNEMP & TLTD & HOUSECOST & \\
\hline UNEMP & 1 & 0.209 & -0.680 & \\
\hline TLTD & 0.209 & 1 & -0.159 & \\
\hline HOUSECOST & -0.680 & -0.159 & 1 & \\
\hline
\end{tabular}

Also, TLTD ratio seems to have positive influence on the NPL. A $1 \%$ rise/shrink of the ratio leads to a $13 \%$ change of NPL ratio in the same direction. On the contrary, real estate prices seem to have a negative relationship with NPLs.

In any case, unemployment rate could be removed if we wanted to be stricter in terms of multicollinearity. The results are presented in Table 6. According to Table 6, both variables are statistically significant. TLTD rate causes a positive $14 \%$ change on the NPL rate and real estate prices index causes a $27 \%$ negative on. 
Table 6: Estimation Results

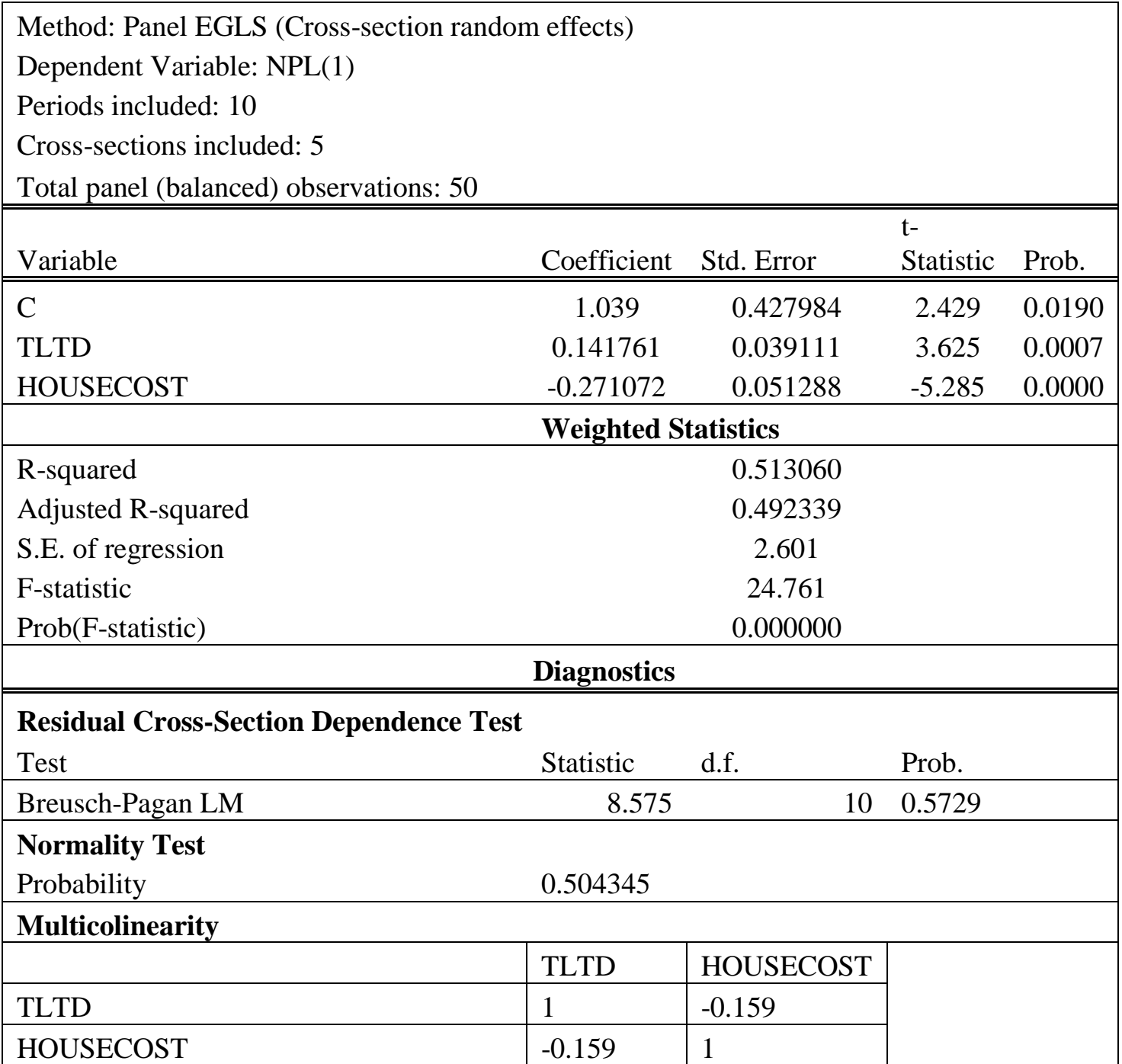

The positive relationship of NPLs with the LDR indicates that among the loans granted by banks, there were many high-risk loans, which even in the short term were converted into non-performing loans.

Regarding real estate (housing) prices there is a negative relationship with NPLs which indicates that NPLs rate decrease when the real estate prices rise and vice versa. On the contrary, when real estate prices decrease income shrinks. So, high real estate prices mean that the value of banks' mortgages raises.

\section{Conclusions}

This study tried to identify the main parameters that influence PIIGS' NPLs using panel data for period 2008-2018 and applying random effects Generalized Least Square Method. Results indicate a significant positive impact of unemployment and LDR on the evolution of NPLs and a negative by the real estate prices.

Findings are in line with previous studies results. In regard to PIIGS, we conclude that all countries' (Greece, Spain, Italy, Portugal and Ireland) NPLs' have a significant positive effect with the unemployment rate (Louzis et al (2010); Makri et al (2014); Messai and Jouini (2013); Skarica (2013)) 
and a negative one with real estate prices (Rinaldi and Sanchis-Arellano (2006)). Additionally, the positive relationship of NPLs with the LDR indicates that among the loans granted by banks, there were many high-risk loans, which even in the short term were converted into non-performing loans.

The significance of unemployment rate is expected because unemployment leads to lower income and increased debts. Therefore, changes in the unemployment rate may lead to changes in the NPL ratio in the same direction.

Regarding real estate (housing) prices there is a negative relationship with NPLs which indicates that NPLs rate decrease when the real estate prices rise and vice versa. On the contrary, when real estate prices decrease income shrinks. So, high real estate prices mean that the value of banks' mortgages raises.

The empirical results indicate cooperation between creditors, borrowers and regulatory agencies/authorities/institutions. The state should guarantee the securitization of non-performing loans. There should also be developed a legislative framework in order to hinder the activity of strategic defaulters.

Banks should provide accurate information to the regulatory agencies on the quality of their loans and follow the instructions of the ECB. Their lending policy should be based on accurate estimates and transparent procedures. Also, borrowers need to be motivated to be cooperative and to provide complete information about their property and assets to the banks. In terms of real estate prices, they should be maintained at levels that will facilitate the servicing of loans.

However, this study has some limitations in regard to the relationship among NPLs and specific financial ratios, such as ROA and lending rates. On the other hand, we could also employ some qualitative variables, such as the degree of transparency in financial transactions, the degree of transparency around real estate transactions and the evaluations of bank executives. Finally, an increased number of observations is needed, to receive more consistent results.

\section{References}

Abid, L., Ouertani, M.N. \& Zouari- Ghorbel, S. (2014). Macroeconomic and Bank-Specific Determinants of Household's Non-Performing Loans in Tunisia: a Dynamic Panel Data. In T. S. (TSFS) (Ed.), Procedia Economics and Finance 13. 13, pp. 58-68. Tunisia: Elsevier."

Anastasiou, D., Louri \& H., Tsionas, M. (2017). Non- Performing Loans in the Euro Area: Are CorePeripher Banking Markets Fragmented?. Bank of Greece, Working Paper No 219

Ari, A.Chen, S. \& Ratnowski, L. (2019). The Dynamics of Non-Performing Loans During Banking Crises: A New Database. IMF Working Paper 19/272. Washington: International Monetary Fund.

Arpa, M., Giulini, I., Ittner, A. \& Pauer, F. (2001). The influence of macroeconomic developments on Austrian banks: implications for banking supervision. BIS Papers, 1, pp. $91-116$

Baholli, F.,Dika,I. \& Xhabija, G (2015). Non-Performing Loans with Econometric Model: Albanian Case. Mediteranian Jounal of Social Sciences, Vol 6 No 1.

Bank of Greece (2019). Bank of Greece Monetary Policy Report 2019. Available at https://www.bankofgreece.gr/Publications/NomPol20182019.pdf (Accessed 14 May 2020)

Beck, R., Jakubik, P. \& Piloiu, A. (2013). Non-Performing Loans: What Matters in Addition to the Economic Cycle?. ECB Working Paper No 1515, ECB.

Berge, T.O. \& Boye, K.G. (2007). An Analysis of Bank's Problem Loans. Norges Bank Economic Bulletin 78, 65-76

Berger, A.N \& De Young R. (1997). Problem loans and cost efficiency in commercial banks. Journal of Banking and Finance, 21, 849-870

Bonfondi, M. \& Ropele, I. (2011). Makroeconomic determinants of bad loans: evidence from Italian banks. Occasional Papers, p 89 
Charalambakis, E., Dendramis, Y., Tzavalis, E. (2017). On The Determinants of NPLs: Lessons from Greece. Bank of Greece Working Paper 220, p 4

ECB-Banking Supervision (2020). Non-Performing Loans. Available at https://www.bankingsupervision.europa.eu/banking/priorities/npl/html/index.el.html

Espinoza, R. \& Prasad, A. (2010). Nonperforming Loans in the GCC banking system and their macroeconomic effects. IMF Working Papers 10/224. Washington: International Monetary Fund

Garciya- Marco, T. \& Robles- Fernandez, M.D. (2008). Risk- taking behaviour and ownership in the banking industry: the Spanish evidence. Journal of Economics and Banks, 60(4), 332-354

Glen, J. \& Mondragon- Velez, C. (2011). Business Cycle Effects on commercial bank loan portfolio performance in developing economies. International Finance Corporation, World Bank Group

Godlewski, C. (2004). Capital regulation and credit risk taking: empirical evidence from banks in emerging market economies. Finance 040903, EconWPA

Louzis, D.P, Vouldis, A.T \& Metaxas, V.L. (2010). Makroeconomic and bank- specific determinants of non performing Loans in Greece: a comparative study of mortage, business and consumer loan portfolios. Working Paper, vol 118, Bank of Greece

Makri, V. , Tsagkanos, A. \& Bellas, A. (2012). Determinants of Non Performing Loans: The case of Eurozone. PANOECONOMICUS, 2, pp. 193- 206

Messai, A.S \& Jouini, F. (2013). Micro and Macro Determinants of Non- performing Loans. International Journal of Economics and Financial Issues, ISSN: 2146-4138, Vol. 3, No. 4, pp.852-860.

Monokroussos, P., Thomakos, D.D \& Alexopoulos, T.A. (2016). Explaining Non- performing loans in Greece: a comparative study on the effects of recession and banking practices'. Hellenic Observatory Papers on Greece and Southeast Europe, Grease Paper No 101

Nkusu, M. (2011). Nonperforming Loans and Macrofinancial Vulnerabilities in Advanced Economies. IMF Working Paper 11/161. Washington: International Monetary Fund.

Podpiera, J. \& Weill, L. (2008). Bad Luck or Management? Emerging Banking Market Experience. Journal of Financial Stability, 4 (2), 135-148

Quagliarello, M. (2007). Banks' Riskiness Over the Business Cycle: a Panel Analysis on Italian Intermediaries. Applied Financial Economics, 17(2), 119-138.

Rinaldi, L. \& Sanchis-Arellano, A. (2006). Household debt sustainability: What explains household nonperforming loans? An empirical analysis. ECB Working Paper, $\mathrm{n}^{\circ} 570$.

Salas, V. \& Saurina, J. (2002). Credit risk in two institutional regimes: Spanish commercial and savings banks. Journal of Financial Services Research, 22: 3, pp 203-224

Skarica, B. (2013). Determinants of Non- Performing Loans in Central and Eastern European Countries. Working Paper 13-07. Faculty of Economics and Business, Zagreb

Verbeek, M. (2012) A Guide to Modern Econometrics (4th Edition). West Sussex, John Wiley \& Sons Ltd.

Wooldridge J. (2009). Introductory Econometrics. A Modern Approach. Fifth Edition,pp 448-676. 